\title{
Monitoring progress toward United Nations commitments: characteristics of Canadian legislation to promote tobacco control, physical activity and healthy eating. A descriptive study
}

\author{
Katerina Maximova PhD, Kim D. Raine PhD, Christine Czoli PhD, Jennifer O’Loughlin PhD, \\ John Minkley JD, Kendall Tisdale MPH, Tania Bubela PhD JD
}

\section{Abstract}

Background: Legal interventions are important mechanisms for chronic disease prevention. Since Canadian laws to promote physical activity and healthy eating are growing, we compared the characteristics of legal interventions targeting physical activity and healthy eating with tobacco control laws, which have been extensively described.

Methods: We reviewed 718 federal, provincial and territorial laws promoting tobacco control, physical activity and healthy eating captured in the Prevention Policies Directory between spring 2010 and September 2017. We characterized the legislation with regard to its purpose, tools to accomplish the purpose, responsible authorities, target location, level of coerciveness and provisions for enforcement.

Results: Two-thirds (67.9\%) of tobacco control legislation had a primary chronic disease prevention purpose (explicit in $5.3 \%$ of documents and implicit in $62.6 \%$ ), and $29.5 \%$ had a secondary chronic disease prevention purpose. One-quarter (27.0\%) of physical activity legislation had a primary chronic disease prevention purpose (explicit in $8.8 \%$ of documents and implicit in $18.1 \%$ ), and $53.0 \%$ had a secondary chronic disease prevention purpose. In contrast, $69.3 \%$ of healthy eating legislation had no chronic disease prevention purpose. Tobacco control legislation was most coercive (restrict or eliminate choice), and physical activity and healthy eating legislation was least coercive (provide information or enable choice). Most tobacco control legislation $(85.8 \%)$ included provisions for enforcement, whereas $47.4 \%$ and $24.8 \%$ of physical activity and healthy eating laws, respectively, included such provisions. Patterns in responsible authorities, target populations, settings and tools to accomplish its purpose (e.g., taxation, subsidies, advertising limits, prohibitions) also differed between legislation targeting tobacco control versus physical activity and healthy eating.

Interpretation: Legislative approaches to promote physical activity and healthy eating lag behind those for tobacco control. The results serve as a baseline for building consensus on the use of legislation to support approaches to chronic disease prevention to reduce the burden of chronic disease in Canadians.

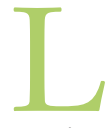

egislative and regulatory approaches are important mechanisms for chronic disease prevention whereby governments use law to create health-supporting environments that enable behaviour change. ${ }^{1-3}$ Growing evidence supports the use of legal interventions (e.g., taxation; appropriate packaging, labelling and composition standards; marketing restrictions) as key components within a comprehensive chronic disease prevention strategy. ${ }^{4-7}$ At the United Nations high-level meeting on the prevention and control of noncommunicable diseases in September 2018, Canada and other governments reaffirmed commitment to urgent implementation of priority interventions - the "best buys" - targeting lifestyle behaviours ${ }^{6-8}$ to accelerate action on reducing the escalating burden of chronic disease. ${ }^{9}$ Best buys are evidence-based and cost-effective, and have major public health impact. They consist of predominantly legal and regulatory interventions, such as bans on industrial trans fats and taxation on sugar-sweetened beverages. ${ }^{6-8}$

Competing interests: None declared.

This article has been peer reviewed.

Correspondence to: Katerina Maximova, katerina.maximova@ ualberta.ca

CMAJ Open 2019. DOI:10.9778/cmajo.20190049 
Enactment of legislation has been central to tobacco control in Canada, leading to considerable progress in curbing tobacco use. ${ }^{10}$ The use of law is enshrined in the World Health Organization Framework Convention on Tobacco Control, a legally binding treaty. ${ }^{11}$ Building on lessons from tobacco control can help accelerate progress in developing public regulations to promote physical activity and healthy eating. ${ }^{12,13}$ In Canada and other jurisdictions, tobacco control policies have been identified, described and evaluated extensively. ${ }^{14-18}$ Legal interventions targeting physical activity and healthy eating are increasing, ${ }^{19-23}$ with recent Canadian studies examining the effects of provincial bans of food and beverage advertising on the quality and quantity of advertised products ${ }^{24-26}$ and of provincial bans of junk food in schools on overweight and obesity in children. ${ }^{27}$ To provide a baseline for measuring progress toward United Nations commitments and to build Canadian consensus on the use of law for chronic disease prevention, we need to compare legal interventions targeting physical activity and healthy eating to tobacco control laws. Guided by Rogers' ${ }^{28}$ diffusion of innovations framework, we characterized Canadian federal, provincial and territorial legislation promoting tobacco control, physical activity and healthy eating with regard to its purpose, tools to accomplish the purpose, responsible authorities, target location, level of coerciveness and provisions for enforcement.

\section{Methods}

\section{Setting}

Legal interventions pertaining to chronic disease prevention in Canada constituted the general setting for this study.

\section{Data sources}

The Prevention Policies Directory (PPD) is a regularly updated, comprehensive online inventory developed and curated by the Canadian Partnership Against Cancer and modelled on the US National Cancer Institute State Cancer Legislative Database. It is populated by a Web-scanning technology by Lexum Informatique Juridique (lexum.com) that scans monthly current and archived content of more than 200 websites. ${ }^{29}$ The technology was developed and validated to ensure that it captures publicly available legislation from all federal, provincial and territorial government websites. It also extracts legislation from the Canadian Legal Information Institute (CanLII), which provides centralized access to a comprehensive virtual library of consolidated Canadian laws from all jurisdictions that are uploaded monthly (http://canlii. org/). ${ }^{29}$ Captured documents are scored against multiple Boolean queries for relevance and reviewed by a curator for quality assurance. A detailed description of the PPD design and methodology has been published elsewhere. ${ }^{29}$

\section{Design}

For each document entered into the PPD between spring 2010 and September 2017, the PPD contains descriptive information (document type, title, geographic location, targeted risk factor, year) and includes a link to the document on a government website or CanLII. We used PPD descriptive data to identify federal, provincial and territorial legislation targeting tobacco control, physical activity, the built environment and healthy eating that came into effect between 1980 and September 2017. We included as legislation statutes, regulations, codes and bills that received royal assent. We combined legislation targeting the built environment (e.g., roads, buildings, infrastructure and parks, human-made landscape and preservation of the natural environment for recreation) and physical activity (e.g., physical education standards, child fitness tax credits) because improving the built environment also improves opportunities for physical activity. ${ }^{30}$ A "general" category comprised broad legislation concerning chronic disease prevention that made no specific reference to tobacco control, physical activity or healthy eating (e.g., provincial and territorial public health acts). ${ }^{29}$

Two coders trained in law and public health independently extracted the data from the text of each legislative document using a coding manual that described the coding criteria. For 3 variables (purpose, tools to accomplish the purpose, level of coerciveness), the coding criteria are well established, as described below. The coding criteria for the 3 other variables (ministry responsible, target location, enforcement provisions) were developed de novo. In pilot work, 2 team members (J.M. and K.M.) each coded 100 diverse legislative documents to ensure that our coding system consistently differentiated policies in terms of strength (e.g., legislation that bans smoking in public places should be scored high, whereas legislation concerning healthy eating that lacks provisions to address chronic disease prevention should be scored low). Last, we consulted public health law experts at the University of Alberta's Health Law Institute, the Public Health Agency of Canada and the World Health Organization to ensure that our measures were comprehensive and had face and content validity. Coding disagreements generally arose from texts with vague terminology or inconsistent use of terms. In the few cases $(<5)$ of unresolved disagreement, we reported the data extracted by the legal coder.

\section{Outcome measures}

We used standard legal analysis methods, ${ }^{31}$ including validated statutory interpretation methods, to interpret purpose, ${ }^{32}$ Gostin's ${ }^{33}$ criteria to assess tools to accomplish the purpose and the Nuffield Council on Bioethics policy framework to assess level of coerciveness. ${ }^{34} \mathrm{We}$ derived the statutory purpose from the objective or purpose statements of each legislative document, which declare the intention of the legislators. ${ }^{32,35}$ We distinguished whether the legislation had a primary or secondary chronic disease prevention purpose based on whether an entire piece of legislation or a portion thereof, respectively, focused on chronic disease prevention. ${ }^{32}$ For example, Prince Edward Island's Smoke-free Places Act ${ }^{36}$ has a primary chronic disease prevention purpose to reduce tobacco use and exposure, whereas Alberta's Child Care Licensing $A c t^{37}$ has a secondary chronic disease prevention purpose; its primary purpose is licensing and regulation of daycare centres, with provisions stipulating serving of healthy 
foods or prohibition of smoking on day care premises. We categorized the intent of the legislation as explicit versus implicit based on whether the primary purpose was stated in the preamble or implied, respectively. ${ }^{35} \mathrm{We}$ coded legislation that did not mention chronic disease prevention as having no chronic disease prevention purpose. For example, the purpose of Canada's National Dairy Code ${ }^{38}$ is to regulate the production and processing of dairy products, with no reduction targets for trans fat or sodium relevant to chronic disease prevention.

We based our assessment of tools or means through which the legislation accomplished its purpose on Gostin's ${ }^{33}$ criteria, which include 1) economic incentives and disincentives that raise revenue and allocate resources for the good of the population (e.g., tax breaks for enrolment of children in physical activity programs), 2) interventions that alter the informational environment (e.g., nutrition labelling) and 3) direct regulation, which involves monitoring of compliance and punishment of noncompliance with health and safety standards (e.g., restriction on sales of tobacco to minors). The classification of tools is summarized in Table 1.

We determined the responsible ministry from the legislation or from public government websites. The responsibility for the legislation, including amendments and enactment of regulations, may be the same as or distinct from administrative responsibility, which may be delegated to public bodies (captured under the coding of tools). We assigned a name to each ministry according to the most common name in use

\begin{tabular}{|ll|}
\hline $\begin{array}{l}\text { Table 1: Classification of tools used to accomplish the } \\
\text { legislation purpose }{ }^{32}\end{array}$ \\
\hline Tool & $\begin{array}{l}\text { Impose taxes, provide tax credits or } \\
\text { exemptions }\end{array}$ \\
\hline Tax and spend & $\begin{array}{l}\text { Directly impose restrictions such as } \\
\text { prohibitions and licensing on } \\
\text { individuals and businesses }\end{array}$ \\
\hline Direct regulation & $\begin{array}{l}\text { Grant of causes of action in tort to } \\
\text { government or others }\end{array}$ \\
\hline $\begin{array}{l}\text { Indirect regulation } \\
\text { through tort system }\end{array}$ & $\begin{array}{l}\text { Repeal of legislative provisions that } \\
\text { disincentivize desired public health } \\
\text { behaviours }\end{array}$ \\
\hline Deregulation & $\begin{array}{l}\text { Grant legal authority to public or } \\
\text { administrative body (e.g., school } \\
\text { board) empowering it to act and set its } \\
\text { duties }\end{array}$ \\
\hline $\begin{array}{l}\text { Delegation of } \\
\text { regulation to public } \\
\text { administrative body }\end{array}$ & $\begin{array}{l}\text { Mandate product labelling, instructions } \\
\text { for safe use, disclosure of ingredients } \\
\text { or health warnings, limits on harmful or } \\
\text { misleading advertising }\end{array}$ \\
\hline $\begin{array}{l}\text { Alter informational } \\
\text { environment }\end{array}$ & $\begin{array}{l}\text { Grant ability to alter or regulate built } \\
\text { environment or what people can do } \\
\text { with built environment }\end{array}$ \\
\hline $\begin{array}{l}\text { Amprove health by targeting social or } \\
\text { environment } \\
\text { disadvantaged populations }\end{array}$ \\
\hline Alter built environment of
\end{tabular}

across Canadian jurisdictions (e.g., ministry of health). We assessed the target location for the application of the legislation from the text or inferred it from the content and purpose of the legislation. ${ }^{39}$

We assigned a level of coerciveness based on the Nuffield Council on Bioethics policy framework, ${ }^{34}$ which differentiates 8 levels of intervention, from least to most restrictive of individual rights: 1 ) do nothing (simply monitor the situation), 2) provide information (inform and educate people [e.g., health warnings, nutrition labels]), 3) enable choice (support behaviour change), 4) guide choices by changing default options (make "healthier" choices the default), 5) guide choice through incentives (financial and other incentives to guide people to pursue healthy activities), 6) guide choice through disincentives (financial and other disincentives to guide people not to pursue unhealthy activities), 7) restrict choice (regulate to restrict options available) and 8) eliminate choice (regulate to eliminate choice entirely). ${ }^{34,40}$

We assessed whether the legislation included enforcement provisions (appointment and duties of officers and inspectors, or powers of audit, search, seizure or inspection) and specified conditions for an offence or penalty: in the legislation itself, in the enacting legislation of regulations or under another piece of legislation. ${ }^{41}$

\section{Data analysis}

The data were entered into Microsoft Excel and analyzed with the Stata 13 statistical package (Stata Corp.).

\section{Ethics approval}

The University of Alberta Research Ethics Board approved the study protocol.

\section{Results}

We identified 718 pieces of legislation that met the inclusion criteria (Figure 1). Interrater reliability was high (agreement $>90 \% ; \kappa>0.90)$. Table 2 shows the distribution of legislation according to type and targeted risk factor (provincial distribution is found in Appendix 1, Supplemental Table S1, available at www.cmajopen.ca/content/7/4/E745/suppl/DC1). Twothirds $(67.9 \%)$ of tobacco control legislation had a primary chronic disease prevention purpose, $29.5 \%$ had a secondary prevention purpose, and $2.1 \%$ had no prevention purpose ${ }^{42}$ (Table 3). Just over half (53.0\%) of legislation targeting physical activity had a secondary chronic disease prevention purpose, $27.0 \%$ had a primary prevention purpose, and $20.0 \%$ had no prevention purpose. Two-thirds $(69.3 \%)$ of legislation targeting healthy eating had no chronic disease prevention purpose, $23.8 \%$ had a secondary prevention purpose, and $6.9 \%$ had a primary prevention purpose. A condensed list of the primary purpose of the legislation is found in Appendix 1, Supplemental Table S2.

Most (77.9\%) tobacco control legislation used direct regulation to accomplish its purpose, followed by tax and spend $(17.4 \%)$ and alter informational environment $(16.8 \%)$ (Table 3). Alter built environment was the most common tool 


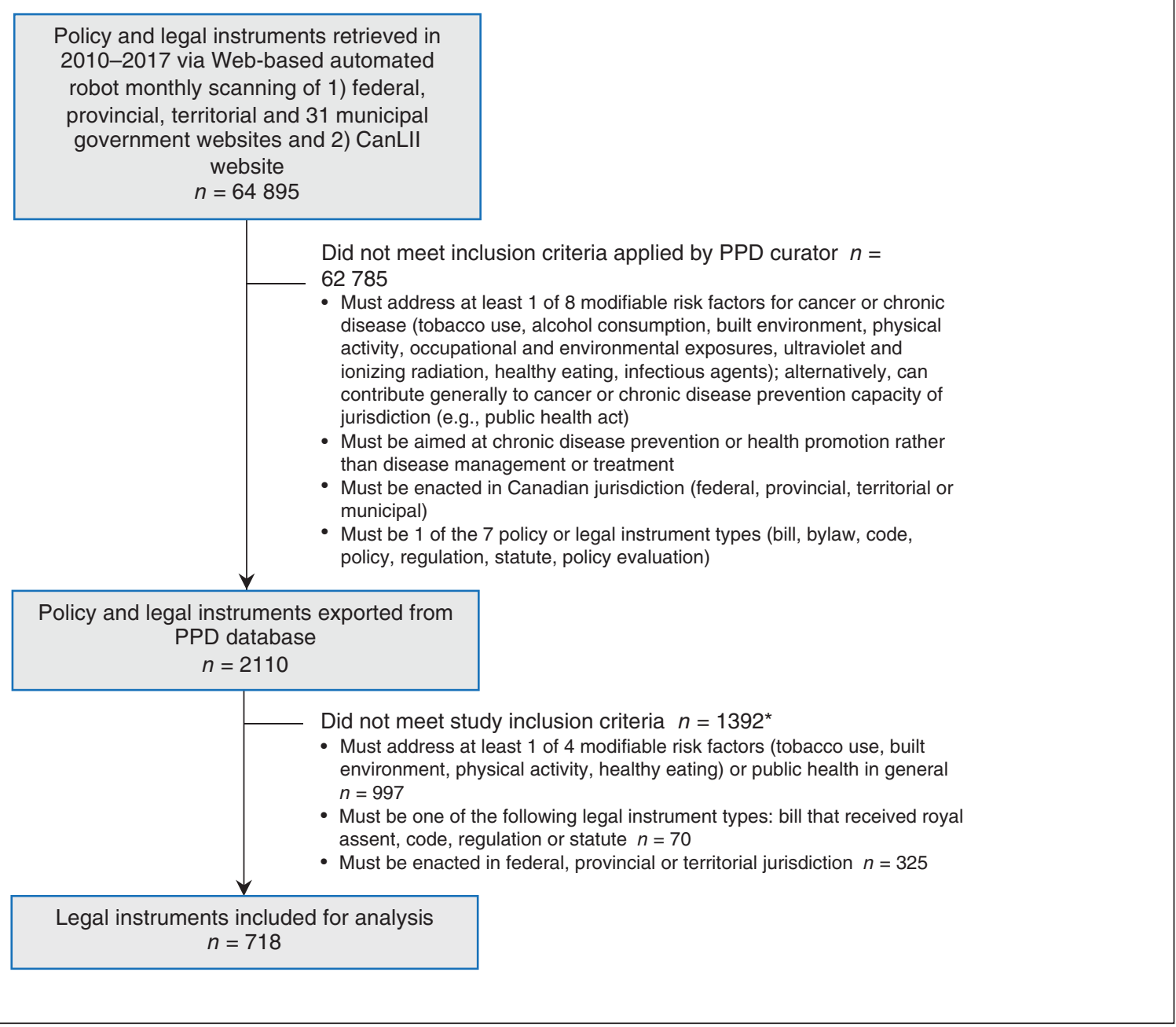

Figure 1: Flow chart showing selection of Prevention Policy Directory (PPD) legislation for analysis. *Criteria applied by study investigators. Note: CanLII = Canadian Legal Information Institute.

\begin{tabular}{|c|c|c|c|c|c|}
\hline \multirow[b]{2}{*}{ Legislation type } & \multicolumn{5}{|c|}{ Risk factor; no. (\%) of documents } \\
\hline & $\begin{array}{c}\text { Tobacco control } \\
n=190\end{array}$ & $\begin{array}{c}\text { Physical activity } \\
n=215\end{array}$ & $\begin{array}{c}\text { Healthy eating } \\
\quad n=101\end{array}$ & $\begin{array}{c}\text { Multiple factors* } \\
\quad n=100\end{array}$ & $\begin{array}{c}\text { Total† } \\
n=718\end{array}$ \\
\hline Statute & $75(39.5)$ & $116(54.0)$ & $42(41.6)$ & $19(19.0)$ & $335(46.7)$ \\
\hline Regulation & $84(44.2)$ & $80(37.2)$ & $47(46.5)$ & $74(74.0)$ & $303(42.2)$ \\
\hline Code & $0(0.0)$ & $1(0.5)$ & $0(0.0)$ & $2(2.0)$ & $3(0.4)$ \\
\hline Bill & $31(16.3)$ & $18(8.4)$ & $12(11.9)$ & $5(5.0)$ & $77(10.7)$ \\
\hline
\end{tabular}

used in physical activity legislation, at $57.7 \%$, followed by regulation through a public body $(29.8 \%)$ and tax and spend $(20.5 \%)$. The legislation targeting healthy eating used direct regulation $(17.8 \%)$, regulation through a public body $(7.9 \%)$ and tax and spend (5.9\%).
For most legislation (44.7\%), the ministry of health held legislative responsibility for tobacco control legislation, followed by finance $(28.4 \%$ ) and justice $(12.6 \%$ ) (Table 4$)$. For physical activity legislation, the ministry of the environment most commonly held legislative responsibility $(24.6 \%)$, 


\begin{tabular}{|c|c|c|c|c|c|}
\hline \multirow[b]{2}{*}{ Variable } & \multicolumn{5}{|c|}{ Risk factor; no. (\%) of documents } \\
\hline & $\begin{array}{c}\text { Tobacco control } \\
n=190\end{array}$ & $\begin{array}{l}\text { Physical activity } \\
\qquad n=215\end{array}$ & $\begin{array}{l}\text { Healthy eating } \\
\quad n=101\end{array}$ & $\begin{array}{c}\text { Multiple factors }{ }^{*} \\
\quad n=100\end{array}$ & $\begin{array}{c}\text { Total† } \\
n=718\end{array}$ \\
\hline \multicolumn{6}{|l|}{ Purpose } \\
\hline Primary - explicit & $10(5.3)$ & $19(8.8)$ & $0(0.0)$ & $5(5.0)$ & $35(4.9)$ \\
\hline Primary - implicit & $119(62.6)$ & $39(18.1)$ & $7(6.9)$ & $7(7.0)$ & $175(24.4)$ \\
\hline Secondary & $56(29.5)$ & $114(53.0)$ & $24(23.8)$ & $75(75.0)$ & $307(42.8)$ \\
\hline No purpose & $4(2.1)$ & $43(20.0)$ & $70(69.3)$ & $12(12.0)$ & $199(27.7)$ \\
\hline Missing & $1(0.1)$ & $0(0.0)$ & $0(0.0)$ & $1(1.0)$ & $2(0.3)$ \\
\hline \multicolumn{6}{|l|}{ Tools to accomplish purpose } \\
\hline Tax and spend & $33(17.4)$ & $44(20.5)$ & $6(5.9)$ & $13(13.0)$ & $100(13.9)$ \\
\hline Direct regulation & $148(77.9)$ & $30(14.0)$ & $18(17.8)$ & $67(67.0)$ & $269(37.5)$ \\
\hline Indirect regulation & $17(8.9)$ & $0(0.0)$ & $0(0.0)$ & $0(0.0)$ & $17(2.4)$ \\
\hline Regulation through public body & $15(7.9)$ & $64(29.8)$ & $8(7.9)$ & $8(8.0)$ & $128(17.8)$ \\
\hline Alter informational environment & $32(16.8)$ & $2(0.9)$ & $4(4.0)$ & $2(2.0)$ & $42(5.8)$ \\
\hline Alter built environment & $3(1.6)$ & $124(57.7)$ & $0(0.0)$ & $39(39.0)$ & $185(25.8)$ \\
\hline Alter socioeconomic environment & $1(0.5)$ & $4(1.9)$ & $3(3.0)$ & $2(2.0)$ & $10(1.4)$ \\
\hline
\end{tabular}

followed by municipalities (19.5\%) and culture (8.8\%). The ministries of health $(9.9 \%)$, social services $(6.9 \%)$ and education $(5.9 \%)$ were most often responsible for legislation targeting healthy eating.

In terms of settings where the legislation applied, workplaces $(21.6 \%)$, public transit $(20.5 \%)$ and enclosed public spaces $(18.4 \%)$ were most often protected by tobacco control legislation (Table 4). Municipalities were most often covered by physical activity legislation (27.9\%), followed by outdoor nonurban spaces $(22.3 \%)$. Finally, healthy eating legislation targeted schools (6.9\%), child care facilities $(5.9 \%)$, food establishments (5.0\%) and long-term care facilities (5.0\%).

Tobacco control legislation was most restrictive of individual rights across all periods (Figure 2). It most commonly eliminated or restricted choice, and its coerciveness increased gradually between 1980 and 2017, with one-third and twothirds of legislation eliminating choice or restricting choice, respectively. Most physical activity legislation enabled choice or guided choice through changing the default policy. Legislation targeting healthy eating was least coercive.

Finally, most tobacco control legislation included provisions for enforcement $(85.8 \%)$ and specified conditions for an offence or penalty (86.8\%), using 1 of 3 mechanisms: in the legislation itself, via delegated authority or in other legislation (Table 5). About one-half (47.4\%) of physical activity legislation and one-quarter $(24.8 \%)$ of healthy eating legislation included such provisions (Table 5). Most tobacco control laws $(86.8 \%)$ specified an offence or a penalty, or both, in the legislation itself or in the enabling legislation of regulations; half $(49.3 \%)$ of physical activity legislation and one-quarter $(25.7 \%)$ of healthy eating legislation did so.

\section{Interpretation}

Three key findings emerged from this study. First, the laws investigated are diverse in purpose, tools to accomplish their purpose, responsible authority, target location, coerciveness and enforcement. Second, although the primary goal of most tobacco control legislation in Canada over the study period was to improve behaviour (i.e., reduce tobacco use or exposure) and prevent chronic disease, few laws targeting physical activity or healthy eating had similar primary goals. Third, the restrictiveness of tobacco control legislation increased gradually since 1980. Although the coerciveness of physical activity and healthy eating legislation appears to have increased between 2010 and 2017, these areas lag behind tobacco control, focusing instead on promotion of best practices and adoption of self-regulatory standards by industry.

The central role of public regulatory approaches within national and international chronic disease prevention strategies recognizes governments as key stakeholders in the development of policy frameworks to create health-supporting environments. ${ }^{6-8}$ The World Health Organization Framework Convention on Tobacco Control has been a catalyst and powerful legal instrument to promote implementation of strong regulatory approaches aimed at reducing the prevalence of tobacco use and exposure to tobacco smoke. Recent assessments of global tobacco control policies showed substantial increases in highest-level implementation of all key demand-reduction measures of the Framework Convention on Tobacco Control and provide convincing evidence that these approaches led to considerable reductions in tobacco use and other tobacco-related outcomes. ${ }^{17,18}$ Implementation of a 


\begin{tabular}{|c|c|c|c|c|c|}
\hline \multirow[b]{2}{*}{ Variable } & \multicolumn{5}{|c|}{ Risk factor; no. (\%) of documents } \\
\hline & $\begin{array}{c}\text { Tobacco control } \\
n=190\end{array}$ & $\begin{array}{c}\text { Physical activity } \\
n=215\end{array}$ & $\begin{array}{l}\text { Healthy eating } \\
\quad n=101\end{array}$ & $\begin{array}{l}\text { Multiple factors* } \\
\quad n=100\end{array}$ & $\begin{array}{c}\text { Total } \\
n=718\end{array}$ \\
\hline \multicolumn{6}{|l|}{ Ministry responsible } \\
\hline Health & $85(44.7)$ & $1(0.5)$ & $10(9.9)$ & $27(27.0)$ & $131(18.2)$ \\
\hline Finance & $54(28.4)$ & $13(6.0)$ & $4(4.0)$ & $7(7.0)$ & $78(10.9)$ \\
\hline Municipal & $0(0.0)$ & $42(19.5)$ & $0(0.0)$ & $5(5.0)$ & $63(8.8)$ \\
\hline Environment & $0(0.0)$ & $53(24.6)$ & $0(0.0)$ & $3(3.0)$ & $56(7.8)$ \\
\hline Education & $2(1.0)$ & $14(6.5)$ & $6(5.9)$ & $5(5.0)$ & $32(4.5)$ \\
\hline Social services & $0(0.0)$ & $5(2.3)$ & $7(6.9)$ & $16(16.0)$ & $32(4.5)$ \\
\hline Justice & $24(12.6)$ & $1(0.5)$ & $1(1.0)$ & $1(1.0)$ & $28(3.9)$ \\
\hline Culture & $0(0.0)$ & $19(8.8)$ & $0(0.0)$ & $7(7.0)$ & $26(3.6)$ \\
\hline Transportation & $10(5.3)$ & $8(3.7)$ & $0(0.0)$ & $1(1.0)$ & $20(2.8)$ \\
\hline Agriculture & $2(1.0)$ & $1(0.5)$ & $3(3.0)$ & $14(14.0)$ & $20(2.8)$ \\
\hline Development & $1(0.5)$ & $12(5.6)$ & $0(0.0)$ & $1(1.0)$ & $14(1.9)$ \\
\hline Employment/labour & $9(4.7)$ & $0(0.0)$ & $0(0.0)$ & $2(2.0)$ & $11(1.5)$ \\
\hline Other & $3(1.6)$ & $46(21.4)$ & 70 (69.3) & $11(11.0)$ & $207(28.8)$ \\
\hline \multicolumn{6}{|l|}{ Target location } \\
\hline Municipalities & $8(4.2)$ & 60 (27.9) & $0(0.0)$ & $9(9.0)$ & $94(13.1)$ \\
\hline Public transit & $39(20.5)$ & $13(6.0)$ & $0(0.0)$ & $4(4.0)$ & $58(8.1)$ \\
\hline Schools & $31(16.3)$ & $12(5.6)$ & $7(6.9)$ & $2(2.0)$ & $56(7.8)$ \\
\hline Food establishments & $25(13.2)$ & $0(0.0)$ & $5(5.0)$ & $24(24.0)$ & $54(7.5)$ \\
\hline $\begin{array}{l}\text { Outdoor nonurban } \\
\text { spaces }\end{array}$ & $1(0.5)$ & $48(22.3)$ & $0(0.0)$ & $4(4.0)$ & $53(7.4)$ \\
\hline Long-term care facilities & $23(12.1)$ & $0(0.0)$ & $5(5.0)$ & $15(15.0)$ & $45(6.3)$ \\
\hline Child care facilities & $15(7.9)$ & $1(0.5)$ & $6(5.9)$ & $19(19.0)$ & $44(6.1)$ \\
\hline Workplaces & $41(21.6)$ & $1(0.5)$ & $0(0.0)$ & $2(2.0)$ & $44(6.1)$ \\
\hline $\begin{array}{l}\text { Recreation and sport } \\
\text { facilities }\end{array}$ & $23(12.1)$ & $9(4.2)$ & $0(0.0)$ & $3(3.0)$ & $36(5.0)$ \\
\hline Enclosed public spaces & $35(18.4)$ & $0(0.0)$ & $0(0.0)$ & $0(0.0)$ & $36(5.0)$ \\
\hline Hospitals & $28(14.7)$ & $0(0.0)$ & $0(0.0)$ & $0(0.0)$ & $29(4.0)$ \\
\hline Universities & $18(9.5)$ & $5(2.3)$ & $1(1.0)$ & $1(1.0)$ & $25(3.5)$ \\
\hline Pharmacies & $14(7.4)$ & $0(0.0)$ & $0(0.0)$ & $0(0.0)$ & $16(2.2)$ \\
\hline
\end{tabular}

comprehensive package that combines interventions and policies, particularly higher taxes and smoke-free environment legislation, is critical for accelerating action. ${ }^{12,13}$

Corroborating international evidence, softer approaches for improving diet and physical activity levels are preferred in Canadian legislation. A systematic assessment of US statelevel legislation aimed at preventing childhood obesity adopted in 2003-2005 showed that bills involving softer tools (school nutrition standards, walking/biking trails, safe routes to school) were more likely to be enacted than bills with stronger tools (snack and soda taxes, menu and product labelling). ${ }^{22}$ Informed by Gostin's ${ }^{33}$ criteria, a systematic review of legislation targeting dietary risk factors enacted in the United
States and the European Union since 2004 also highlighted the limited legislative scope, with provision of information to consumers preferred over taxation and marketing restrictions. ${ }^{23}$ Research in support of stronger legislative and regulatory approaches for improving diet and activity levels is burgeoning and has served to inform an expanded set of best-buy interventions. ${ }^{6}$ Studies in the US suggest that a ban on television advertising of unhealthy foods high in sugar, fat or salt is associated with a $20.5 \%$ decline in overweight/obesity in children. ${ }^{43,44}$ In Canada, the body mass index of schoolchildren declined by 0.05 each year after junk food sales were banned on school property in 6 provinces (i.e., a decline of $1 \mathrm{~kg}$ after $5 \mathrm{yr}) .{ }^{27}$ Despite improvements in the nutritional profile of 


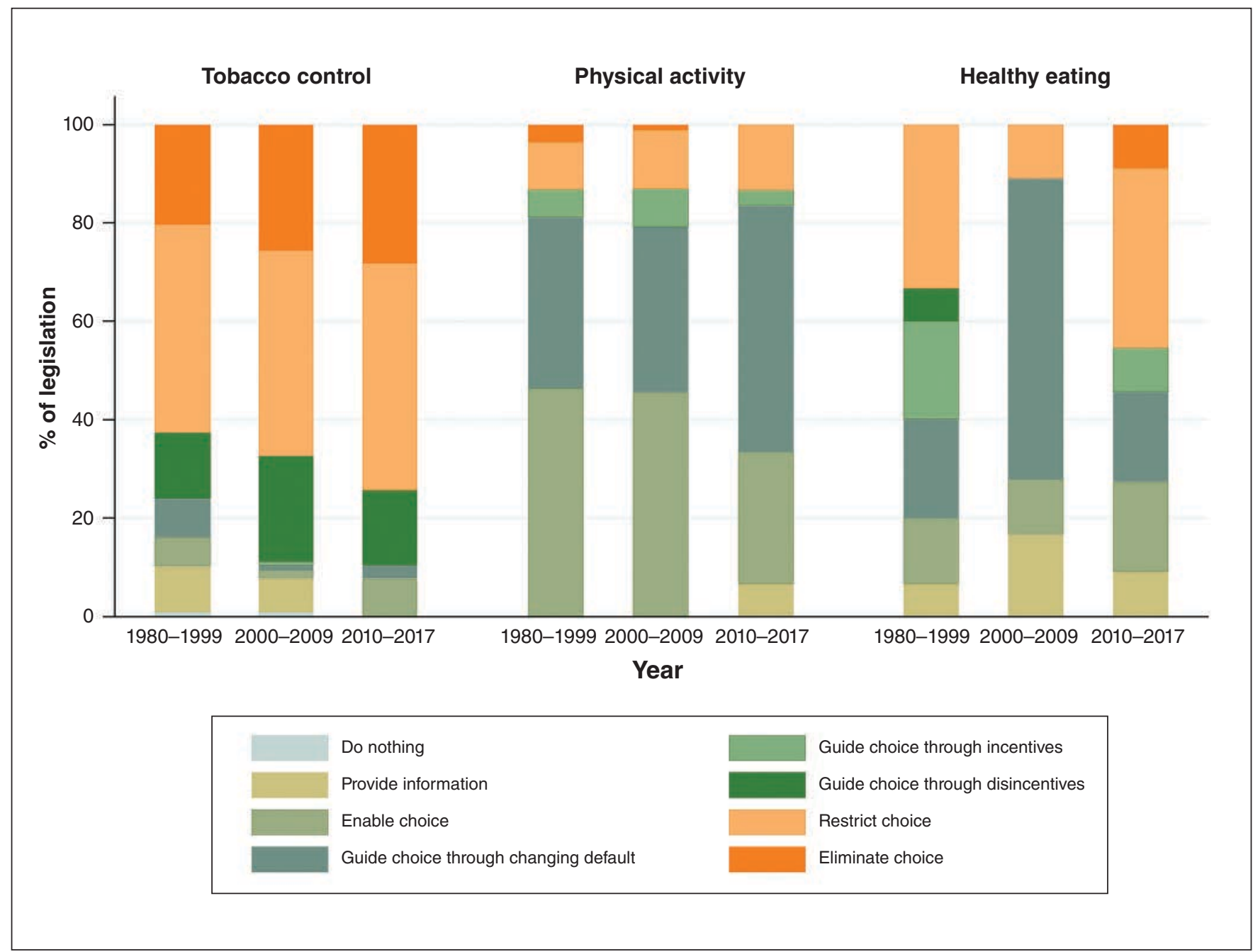

Figure 2: Levels of legislation coerciveness by targeted risk factor and period (based on the Nuffield Council on Bioethics policy framework ${ }^{34}$ ).

\begin{tabular}{|c|c|c|c|c|c|}
\hline \multirow[b]{2}{*}{ Variable } & \multicolumn{5}{|c|}{ Risk factor; no. (\%) of documents } \\
\hline & $\begin{array}{c}\text { Tobacco control } \\
n=190\end{array}$ & $\begin{array}{c}\text { Physical activity } \\
n=215\end{array}$ & $\begin{array}{l}\text { Healthy eating } \\
\quad n=101\end{array}$ & $\begin{array}{l}\text { Multiple factors* } \\
\quad n=100\end{array}$ & $\begin{array}{c}\text { Total† } \\
n=718\end{array}$ \\
\hline \multicolumn{6}{|c|}{$\begin{array}{l}\text { Provision for enforcement } \\
\text { specified }\end{array}$} \\
\hline In legislation itself & $66(34.7)$ & $67(31.2)$ & $12(11.9)$ & $21(21.0)$ & $189(26.3)$ \\
\hline $\begin{array}{l}\text { In enacting or other } \\
\text { legislation }\end{array}$ & $97(51.0)$ & $35(16.3)$ & $13(12.9)$ & $46(46.0)$ & $195(27.2)$ \\
\hline None specified & $27(14.2)$ & $113(52.6)$ & $76(75.2)$ & $33(33.0)$ & $334(46.5)$ \\
\hline \multicolumn{6}{|c|}{ Offence or penalty specified } \\
\hline In legislation itself & $73(38.4)$ & $71(33.0)$ & $14(13.9)$ & $7(7.0)$ & $185(25.8)$ \\
\hline $\begin{array}{l}\text { In enacting or other } \\
\text { legislation }\end{array}$ & $92(48.4)$ & $35(16.3)$ & $12(11.9)$ & $60(60.0)$ & $203(28.3)$ \\
\hline None specified & $25(13.2)$ & $109(50.7)$ & $75(74.3)$ & $33(33.0)$ & $330(46.0)$ \\
\hline
\end{tabular}


food and beverages advertised to children on television in Quebec, ${ }^{24}$ which bans advertising to children less than age 13 years, ${ }^{45}$ the ban does little to limit the amount of food and beverages advertising during prime television viewing time, which highlights the need for monitoring and enforcement. ${ }^{25,26}$ Our results show that few laws focused on healthy eating and physical activity in Canada include provisions for monitoring and enforcement.

\section{Limitations}

Prevention Policies Directory coverage is comprehensive since all laws in Canada must be publicly accessible. However, some laws may not have been captured owing to the scanning method of monitoring and surveillance of prescribed websites. $^{29}$ This limitation is mitigated by the addition of new websites. The CanLII virtual library may also have limitations of completeness (e.g., delays in document transfer and processing) and professional use (i.e., authoritative value, admissibility with relevant authority) listed on its website (www. canlii.org/en/databases.html), which are mitigated in part by the PPD Web-scanning technology, which scans websites in addition to CanLII (e.g., Quebec Department of Justice). The PPD undergoes regular process and outcome evaluation, which shows that it captures a large cross-section of Canadian healthy public policy. ${ }^{29} \mathrm{We}$ excluded municipal bylaws, government policy documents and policy evaluations because our intent was to identify issues and responses important enough to be enshrined in federal, provincial or territorial laws. However, the addition of 325 bylaws from across Canada to our analysis did not change the findings (data not shown). Capturing administrative responsibility was challenging since this information was extracted from the legislation text and publicly accessible government websites. Nonetheless, the analysis showed that responsibility lies across several ministries. Last, we studied characteristics of legislation as it exists "on the books" and not in practice.

\section{Conclusion}

This study highlights substantial lags in using stronger legislative approaches to promote physical activity and healthy eating. Our findings underscore the need for improving capacity in the public health system to develop and implement diverse, comprehensive chronic disease prevention laws that are evidence based, well designed and appropriately targeted. Despite United Nations commitments to accelerate action on reducing the escalating burden of chronic disease, Canadian efforts to enact new laws or inject information relevant to chronic disease prevention into existing laws face challenges that thwart the creation of optimally healthsupportive environments.

\section{References}

1. Magnusson R, Patterson D. Role of law in global response to non-communicable diseases. Lancet 2011;378:859-60.

2. Advancing the right to bealth: the vital role of law. Geneva: World Health Organization; 2017. Available: www.who.int/healthsystems/topics/health-law/health_ law-report/en/ (accessed 2019 June 28).

3. Gostin LO. Law as a tool to facilitate healthier lifestyles and prevent obesity. 7AMA 2007;297:87-90.
4. Cecchini M, Sassi F, Lauer J, et al. Tackling of unhealthy diets, physical inactivity, and obesity: health effects and cost-effectiveness. Lancet 2010;376:1775-84.

5. Gostin LO. Legal and public policy interventions to advance the population's health. In: Smedley BD, Syme SL, editors. Promoting health: intervention strategies from social and behavioral research. Washington: National Academies Press; 2000:390-416.

6. "Best buys" and other recommended interventions for the prevention and control of noncommunicable diseases: updated (2017) Appendix 3 of the Global Action Plan for the Prevention and Control of Noncommunicable Diseases 2013-2020. Geneva: World Health Organization; 2017. Available: www.who.int/ncds/management/ WHO_Appendix_BestBuys.pdf (accessed 2019 June 28).

7. Time to deliver: report of the WHO Independent high-level commission on noncommunicable diseases. Geneva: World Health Organization; 2018. Available: https://apps.who.int/iris/handle/10665/272710 (accessed 2019 June 28).

8. 73/2. Political declaration of the third high-level meeting of the General Assembly on the prevention and control of non-communicable diseases. Agenda item 119, 73rd sess. New York: United Nations; 2018. Available: www.un.org/en/ga/ search/view_doc.asp?symbol=A/RES/73/2 (accessed 2019 June 28).

9. How bealthy are Canadians? A trend analysis of the bealth of Canadians from a healthy living and chronic disease perspective. Ottawa: Public Health Agency of Canada; 2016. Available: www.canada.ca/en/public-health/services/publications/ healthy-living/how-healthy-canadians.html (accessed 2019 June 28).

10. Strong foundation, renewed focus: an overview of Canada's federal tobacco control strategy 2012-2017. Ottawa: Health Canada; 2012. Available: www.canada. $\mathrm{ca} / \mathrm{en} / \mathrm{h}$ alth-canada/services/publications/healthy-living/strong-foundation -renewed-focus-overview-canada-federal-tobacco-control-strategy-2012-17. html (accessed 2019 June 28).

11. WHO Framework Convention on Tobacco Control (FCTC). Geneva: World Health Organization; 2003. Available: www.who.int/fctc/text_download/en/ (accessed 2019 June 28).

12. Yach D, McKee M, Lopez AD, et al. Improving diet and physical activity: 12 lessons from controlling tobacco smoking. BMF 2005;330:898-900.

13. Blouin C, Dubé L. Global health diplomacy for obesity prevention: lessons from tobacco control. 7 Public Health Policy 2010;31:244-55.

14. Asbridge M. Public place restrictions on smoking in Canada: assessing the role of the state, media, science and public health advocacy. Soc Sci Med 2004;58:13-24.

15. Nykiforuk CI, Eyles J, Campbell HS. Smoke-free spaces over time: a policy diffusion study of bylaw development in Alberta and Ontario, Canada. Health Soc Care Community 2008;16:64-74.

16. Eriksen MP, Cerak RL. The diffusion and impact of clean indoor air laws. Annu Rev Public Health 2008;29:171-85.

17. Gravely S, Giovino GA, Craig LV, et al. Implementation of key demandreduction measures of the WHO Framework Convention on Tobacco Control and change in smoking prevalence in 126 countries: an association study. Lancet Public Health 2017;2:e166-74.

18. Chung-Hall J, Craig L, Gravely S, et al. Impact of the WHO FCTC over the first decade: a global evidence review prepared for the Impact Assessment Expert Group. Tob Control 2019;28(Suppl 2):s119-28.

19. Eyler AA, Budd E, Camberos GJ, et al. State legislation related to increasing physical activity: 2006-2012. F Phys Act Health 2016;13:207-13.

20. Cawley J, Liu F. Correlates of state legislative action to prevent childhood obesity. Obesity (Silver Spring) 2008;16:162-7.

21. Monnat SM, Lounsbery MAF, Smith NJ. Correlates of state enactment of elementary school physical education laws. Prev Med 2014;69(Suppl 1):S5-11.

22. Boehmer TK, Luke DA, Haire-Joshu DL, et al. Preventing childhood obesity through state policy. Predictors of bill enactment. Am 7 Prev Med 2008;34: 333-40.

23. Sisnowski J, Handsley E, Street JM. Regulatory approaches to obesity prevention: a systematic overview of current laws addressing diet-related risk factors in the European Union and the United States. Health Policy 2015;119:720-31.

24. Potvin Kent M, Dubois L, Wanless A. A nutritional comparison of foods and beverages marketed to children in two advertising policy environments. Obesity (Silver Spring) 2012;20:1829-37.

25. Potvin Kent M, Dubois L, Wanless A. Self-regulation by industry of food marketing is having little impact during children's preferred television. Int 7 Pediatr Obes 2011;6:401-8.

26. Kent MP, Dubois L, Wanless A. Food marketing on children's television in two different policy environments. Int 7 Pediatr Obes 2011;6:e433-41.

27. Leonard PS. Do school junk food bans improve student health? Evidence from Canada. Can Public Policy 2017;43:105-19.

28. Rogers EM. Diffusion of innovations. 5th ed. New York: Free Press; 2003.

29. Politis CE, Halligan MH, Keen D, et al. Supporting the diffusion of healthy public policy in Canada: the Prevention Policies Directory. Online 7 Public Health Inform 2014;6:e177.

30. Sallis JF, Bauman A, Pratt M. Environmental and policy interventions to promote physical activity. Am 7 Prev Med 1998;15:379-97.

31. McCormack N, Papadopoulos J, Cotter C. The practical guide to Canadian legal research. 4th ed. Toronto: Carswell, Thomson Reuters; 2015.

32. Sullivan R. Sullivan on the construction of statutes, 6th edition. Toronto: LexisNexis Canada; 2014.

33. Gostin LO. Public health law: power, duty, restraint. 2nd ed. Berkeley (CA): University of California Press; 2008. 
34. Public health: ethical issues. London (UK): Nuffield Council on Bioethics; 2007. Available: https://nuffieldbioethics.org/wp-content/uploads/2014/07/Public -health-ethical-issues.pdf (accessed 2019 June 28).

35. Sullivan R. Statutory interpretation in a new nutshell. Can Bar Rev 2003;82:51-82.

36. Smoke-free Places Act, RSPEI 1988, c S-4.2. Available: http://canlii.ca/t/538zc (accessed 2019 Feb. 19).

37. Child Care Licensing Act, SA 2007, c C-10.5. Available: http://canlii.ca/t/52vn4 (accessed 2019 Feb. 19).

38. National Dairy Code: production and processing requirements. 7 th ed. Ottawa: Canadian Dairy Information Centre; 2015. Available: www.dairyinfo. gc.ca/pdf/dairy_code_sept_2015 I e.pdf (accessed 2019 June 28).

39. The Education Act, 1995, SS 1995, c E-0.2. Available: http://canlii.ca/t/533q2 (accessed 2019 Feb. 19).

40. PLACE Research Lab intervention ladder policy analysis framework. Edmonton: Policy, Location and Access in Community Environments (PLACE) Research Lab, School of Public Health, University of Alberta; 2107. Available: http://placeresearchlab.com/wp-content/uploads/2017/11/final_ interventionladder_kab_2017-11-14.pdf (accessed 2019 June 28).

41. Offence Act, RSBC 1996, c 338. Available: http://canlii.ca/t/533tx (accessed 2019 Feb. 19).

42. Regulation respecting the Québec sales tax, CQLR c T-0.1, r 2. Available: http:// canlii.ca/t/53kx2 (accessed 2019 June 20).

43. Chou SY, Rashad I, Grossman M. Fast-food restaurant advertising on television and its influence on childhood obesity. 7 Law Econ 2008;51:599-618.

44. Veerman JL, Van Beeck EF, Barendregt JJ, et al. By how much would limiting TV food advertising reduce childhood obesity? Eur 7 Public Health 2009;19:365-9.

45. Consumer Protection Act, CQLR c P-40.1. Available: http://canlii.ca/t/53h79 (accessed 2019 Feb. 22).
Affiliations: School of Public Health (Maximova, Raine), University of Alberta, Edmonton, Alta; School of Epidemiology and Public Health (Czoli), University of Ottawa, Ottawa, Ont.; School of Public Health (O'Loughlin), University of Montreal, Montréal, Que.; Faculty of Law (Minkley), University of Alberta, Edmonton, Alta.; Canadian Partnership Against Cancer (Tisdale), Toronto, Ont.; Faculty of Health Sciences (Bubela), Simon Fraser University, Vancouver, BC

Contributors: Katerina Maximova conceived and designed the study, and analyzed the data. Kim Raine assisted in study design. Christine Czoli reviewed the literature. Kendall Tisdale assisted with data extraction and management. Tania Bubela conceived the methodology and guided the legislation review. Katerina Maximova interpreted the data, with assistance from Jennifer O'Loughlin. Katerina Maximova and Christine Czoli drafted the manuscript. Kim Raine, Jennifer O'Loughlin, John Minkley, Kendall Tisdale and Tania Bubela revised the manuscript critically for important intellectual content. All of the authors approved the final version to be published and agreed to be accountable for all aspects of the work.

Funding: This work was funded by operating funds through a Career Development Award in Prevention Research from the Canadian Cancer Society to Katerina Maximova (grant 702936).

Supplemental information: For reviewer comments and the original submission of this manuscript, please see www.cmajopen.ca/content/7/4/ E745/suppl/DC1. 